\title{
A mosaic floor from the Late Bronze Age building II of Uşaklı Höyük, central Turkey
}

Anacleto D’Agostino*

Excavations undertaken at $U_{s ̧ a k l ı}$ Höyük in Turkey during 2018 revealed a mosaic stone floor associated with a large building of Hittite date. This unique discovery raises new questions about the origin of mosaic flooring in Near Eastern public architecture of this period.

Keywords: Turkey, Late Bronze Age, Hittite, mosaic flooring, architecture

Uşaklı Höyük is located $20 \mathrm{~km}$ east of Yozgat in a narrow valley north of the Kerkenes Dağ mountain range (Figures 1-2). The main period of occupation dates to the second millennium $\mathrm{BC}$ when the settlement reached its maximum extent.

Fieldwork in 2018 focused on an area (A) on the lower terrace (Figure 3) and revealed a large building of Late Bronze Age date, the plan and masonry of which are typical of public architecture of the Hittite period (Orsi 2018; Mazzoni et al. 2019).

Within area $\mathrm{A}$, part of a rectangular paved floor was revealed in what appears to be a courtyard (Figure 4), to the east of building II (which has been interpreted as a temple of the lower city). The floor is only partially preserved and covers an area of approximately $7 \times 3 \mathrm{~m}$ (Figure 5). It is composed of 3147 pieces of stone of irregular shape and varied dimensions; pebbles are very rare in the arrangement. The stones are laid flat apart from those framing the only visible edge, which are perpendicular so that they form a narrow border. The fragments of stone are loose and are laid directly onto a beaten earth surface so that they are close to, but not touching, one another. The stones are arranged in groups forming geometric patterns and in contrasting colours, alternating between dark and light (Figure 6). The pavement is divided into three rectangular frames with the long axis running south-west to north-east. Each rectangle contains three rows of triangles of different colours including white, light red and black-blue (just two stones are of orange-yellow colour). Only what seems to be the south-eastern edge of the design is well preserved, and this appears as a frame consisting of three narrow parallel bands of stones of white, black-blue and white again; the stones of the external white band are laid with their thin edges uppermost so that they are a narrower final border.

The remains of building II lay directly beneath the present surface, and no evidence of later occupation or other reuse has been found in this sector. After its abandonment, building II was dismantled and probably used over centuries as a quarry for building materials. Only in the north-western corner of area $\mathrm{A}$ is a recent phase of occupation evident, distinguished by later walls belonging to small houses of possibly Roman date overlying the earlier walls of the

\footnotetext{
* Dipartimento di Civiltà e Forme del Sapere, Università of Pisa, via dei Mille 19, Pisa 56126, Italy (Email: anacleto.dagostino@unipi.it)
} 


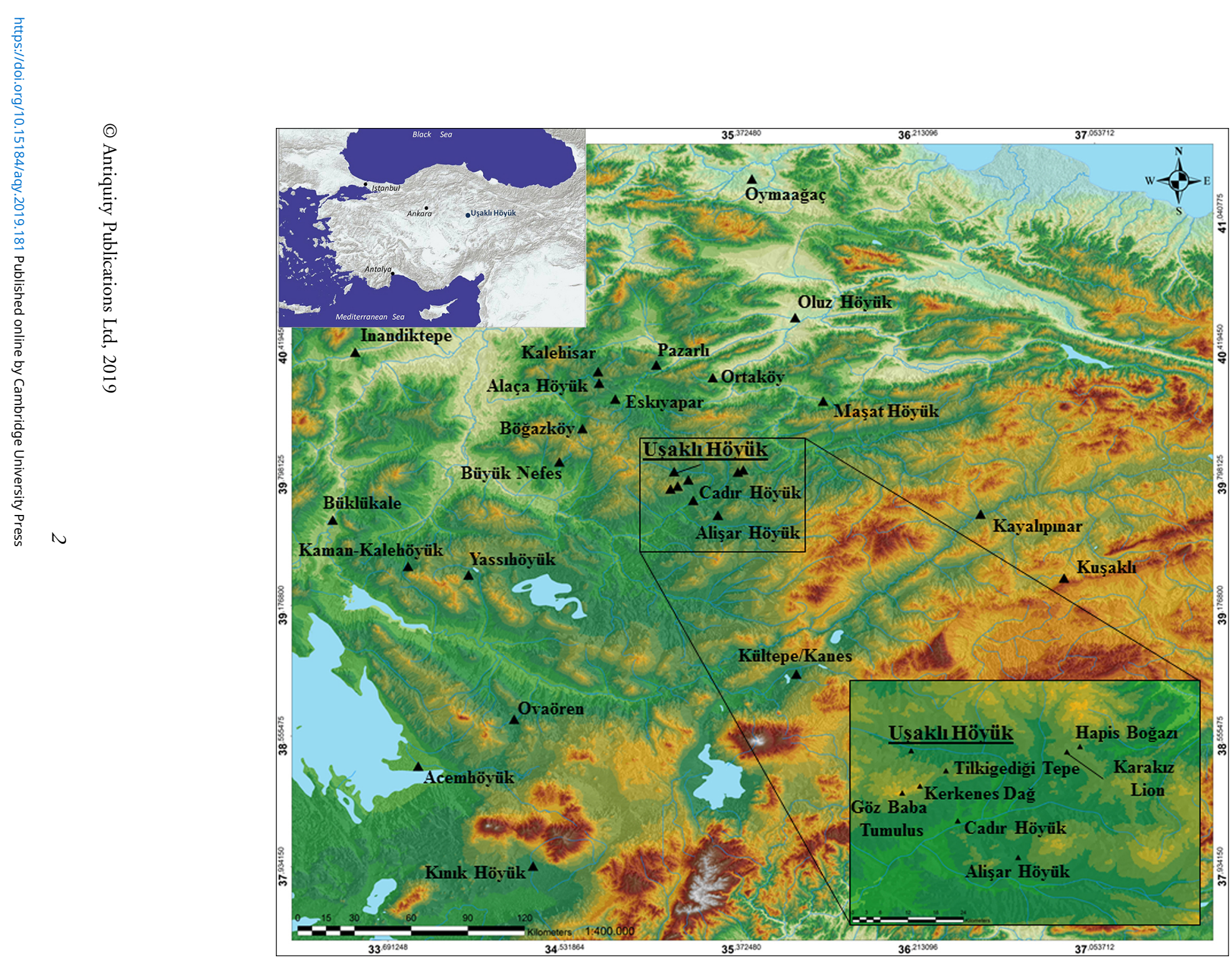

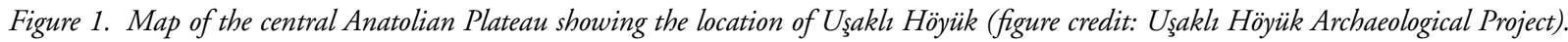




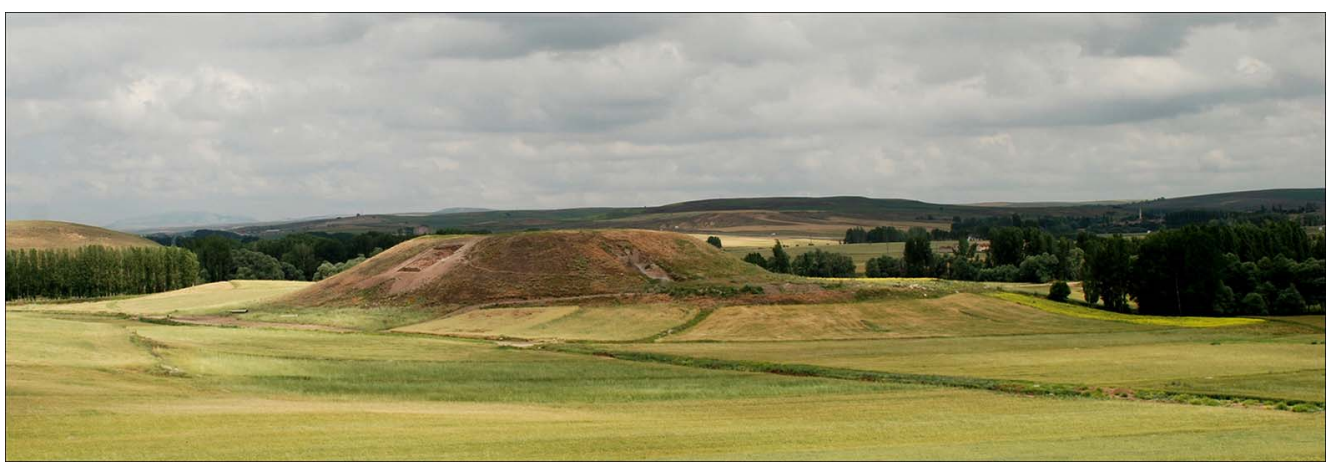

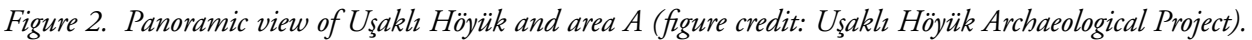

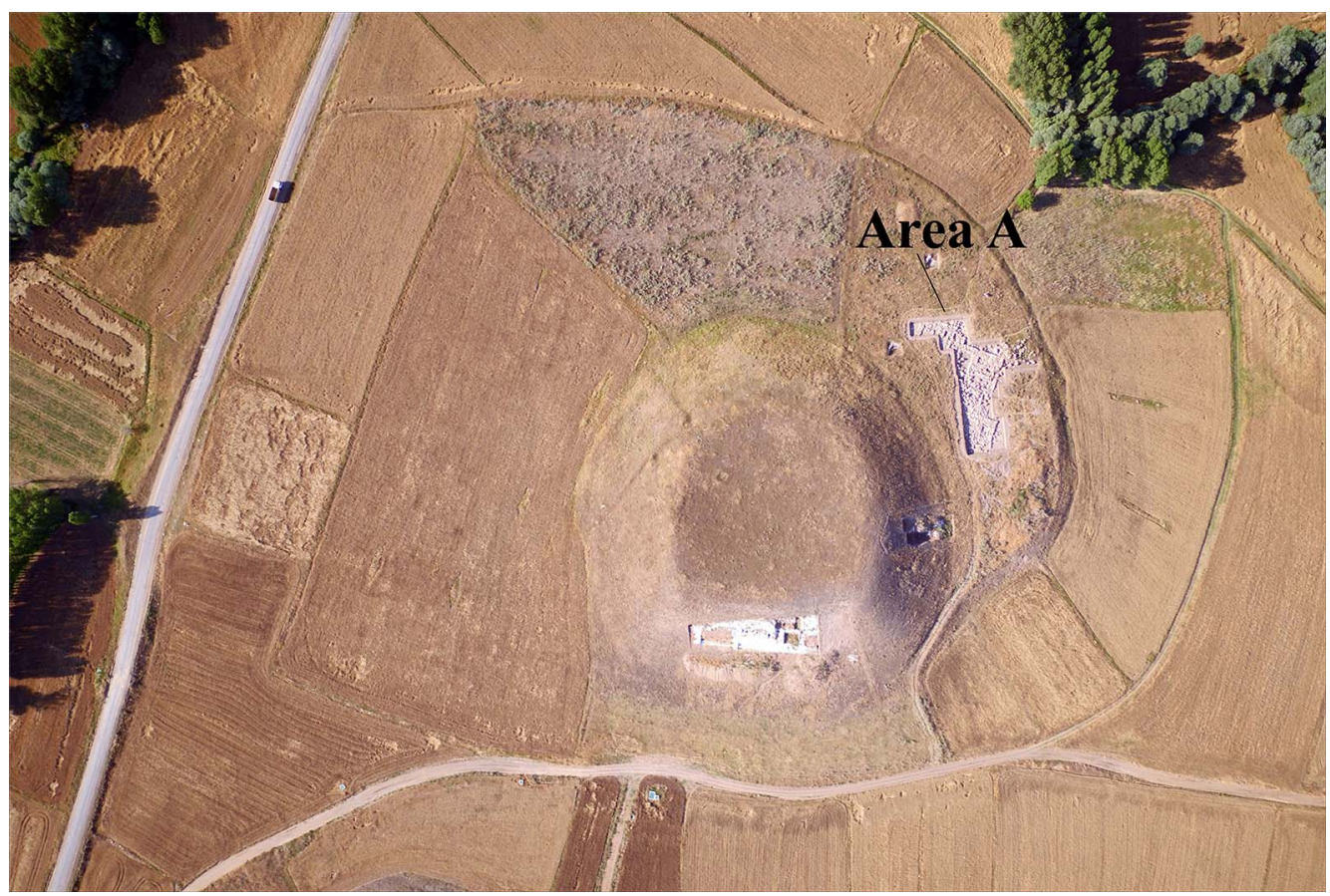

Figure 3. Aerial photograph of the site showing the location of area A (figure credit: Uşaklı Höyük Archaeological Project).

Hittite period. The lower terrace where building II is located has limited evidence for possible Iron Age occupation: there are pot-sherds, beaten earth floors and two alignments of stones, which may represent a temporary occupation without permanent structures.

The stratigraphic relationship between the stone pavement and the nearest eastern wall of building II demonstrates that they are oriented the same with the frame of the mosaic running precisely parallel to the wall. Despite not being in direct contact, it is beyond doubt that they are contemporaneous. The exact alignment cannot be accidental, particularly as the evidence

(C) Antiquity Publications Ltd, 2019 


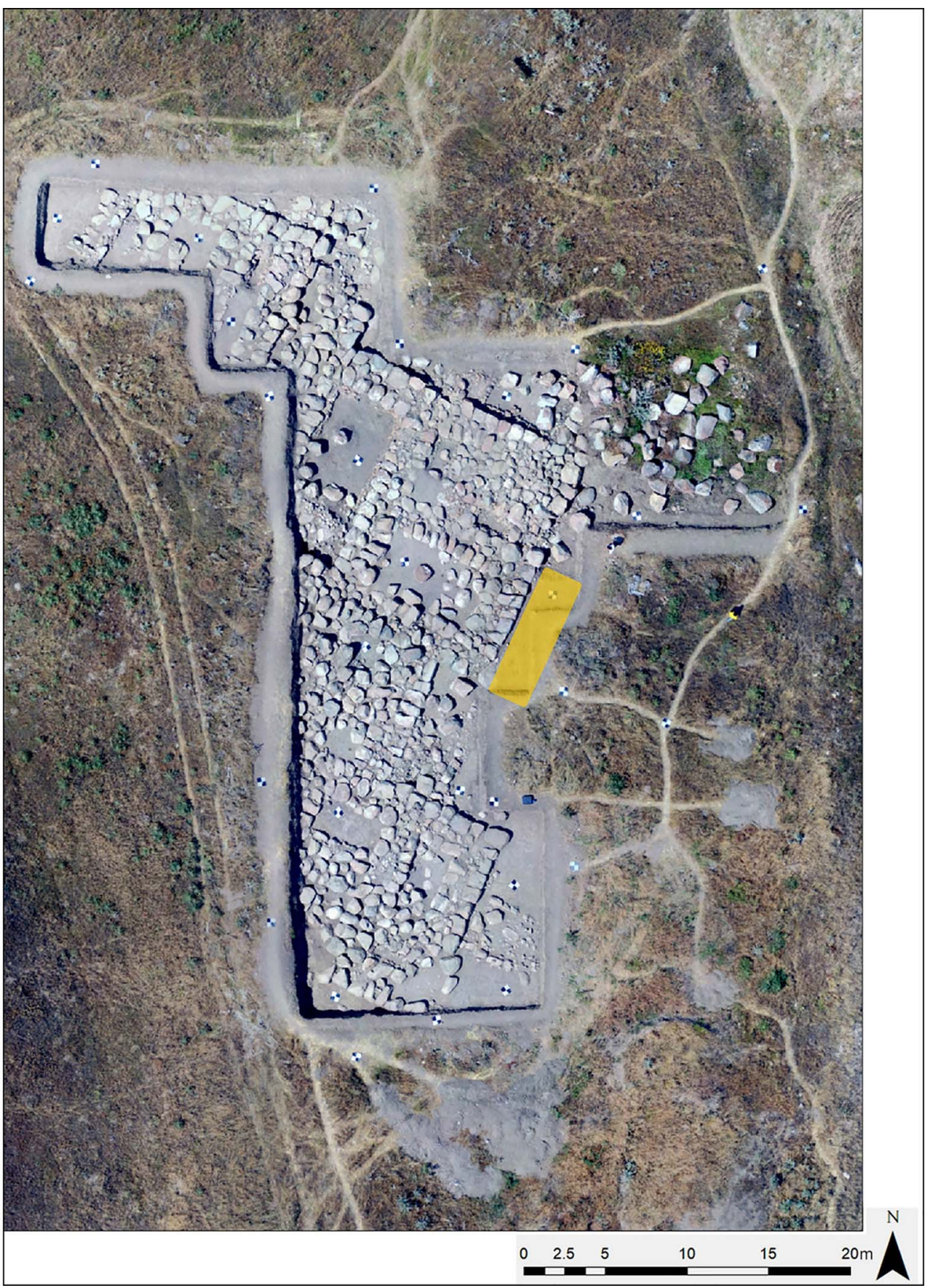

Figure 4. Aerial photograph of the trench showing building II with the location of the mosaic floor highlighted in yellow (figure credit: Uşaklı Höyük Archaeological Project).

(C) Antiquity Publications Ltd, 2019 


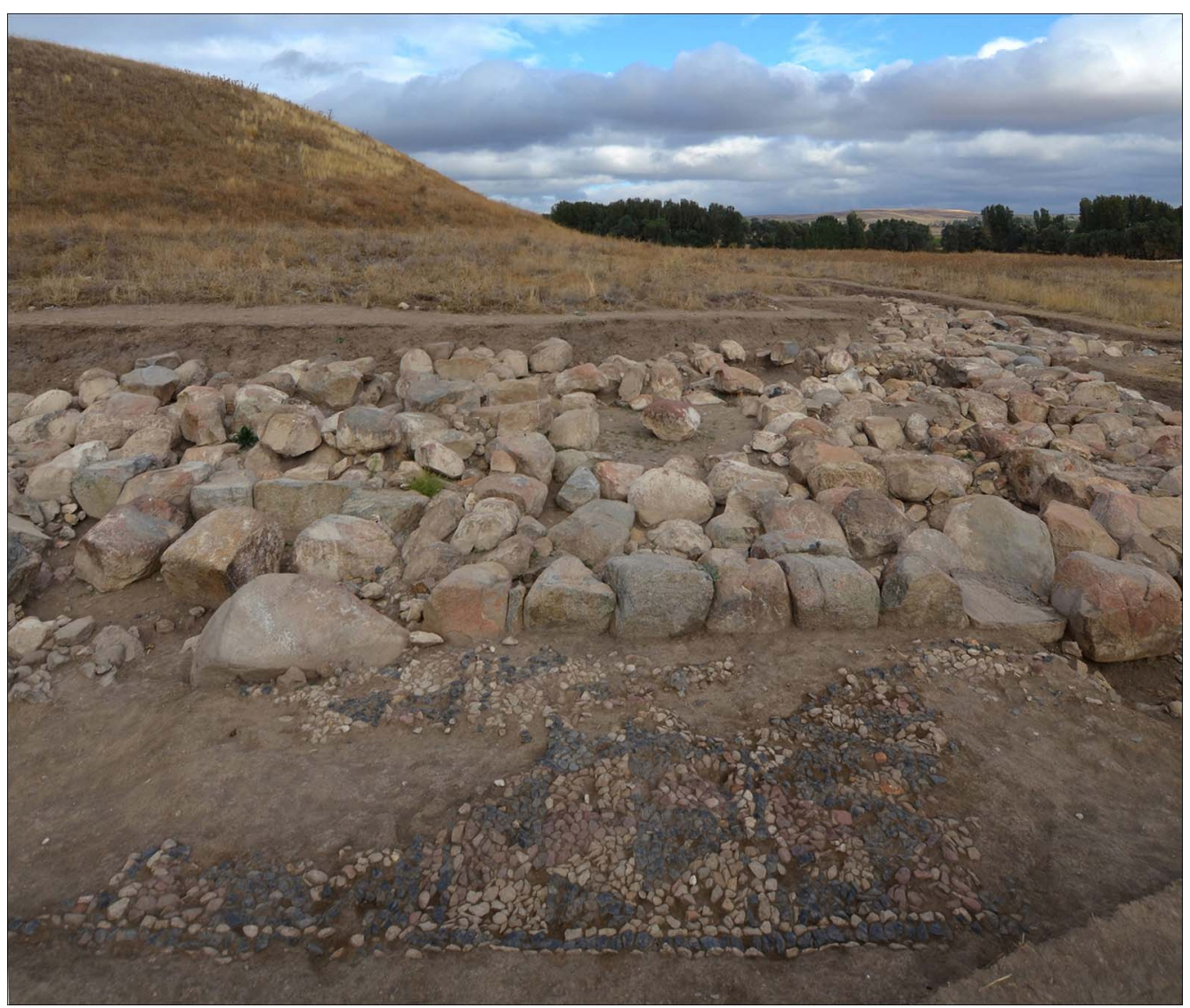

Figure 5. The stone mosaic floor (figure credit: Uşaklı Höyük Archaeological Project).

for later occupation recovered from the area so far suggests a very different type of settlement than that of the apparently official or high-status architecture visible in the Late Bronze Age levels. This was a less permanent use of the site and unlikely to have mosaic flooring.

The use of cobblestones and flagstones for paving external floors, streets and courtyards in central Anatolia during the Hittite period is documented. A rectangular cobblestone floor, parallel to a wall where a gate is located, paves the interior side of the north-eastern portal of the Great Temple of Sarissa (Müller-Karpe 2017: 92-94). In Sapinuwa (modern Ortaköy), similar paving arrangements have been found between external and internal spaces; such alignments are also visible in paved terraces used for ritual purposes (Süel 2008: 13-14, 19, 27, 55, 58). At Boğazköy, the courtyard of the citadel gate of Büyükkale has a pavement of red flagstones, and the area around the Great Temple is also paved with flagstones (Naumann 1955: 145; Neve 1982: 127-28, attachment 40; Mielke 2011: 175).

These floors are clearly deliberately paved, but they are characterised by the use of pebbles or large flagstones, and these are not arranged in decorative patterns. The floor of Uşaklı is unique in that it comprises smaller stones carefully chosen for their shape and colour to allow the creation of geometric designs in specific colours.

(C) Antiquity Publications Ltd, 2019 


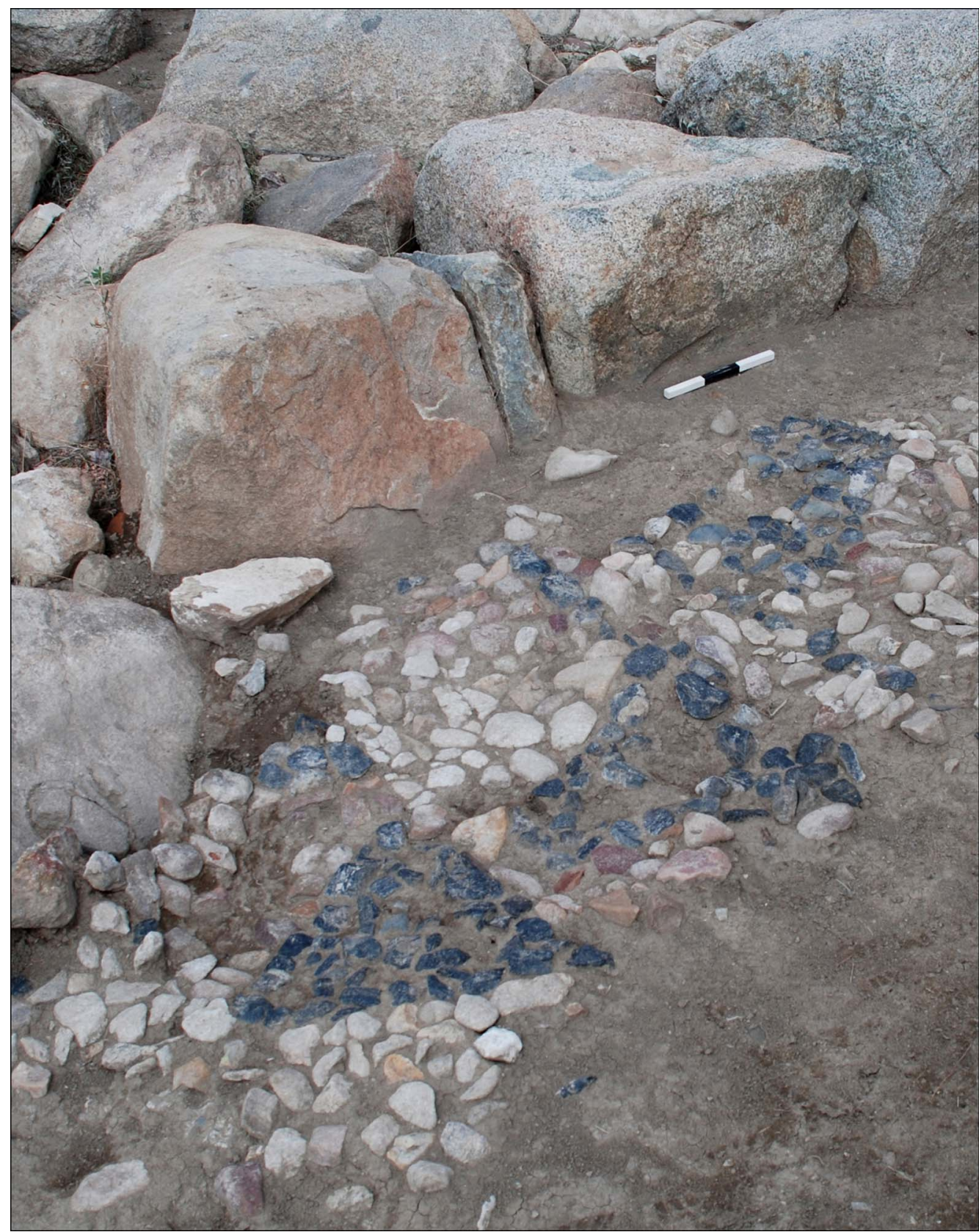

Figure 6. Detail of the mosaic floor (figure credit: Uşaklı Höyük Archaeological Project).

The technique of making mosaic floors using pebbles with different colours is well known during the Iron Age and has been documented in Anatolia, Syria and Upper Mesopotamia. The earliest mosaic floor of the late ninth century BC 'Burned Building'-a large structure in the Phrygian Gordion citadel that was destroyed by fire-comprised very small pebbles of (C) Antiquity Publications Ltd, 2019 
various colours set in a clay bed to create a programme of very sophisticated geometric as well as abstract designs (Young 1965). At Altıntepe, near Erzincan in eastern Anatolia, a pebble mosaic floor associated with the open area west of the temple survives from the Iron Age (Özgüç 1966: $1-2,43$, pl. xvi); this is made from fist-sized pebbles of various colours, but they are randomly set without any obvious pattern.

In other Near Eastern sites, variations of a black-and-white chequerboard appear to be the preferred style of paving. Mosaic floors in this pattern have been found in the open courtyards and passages of the northern Syrian palaces of Arslan Tash and Tell Ahmar, at Tille Höyük and Karkemish on the Euphrates, and at Ziyaret Tepe and Assur on the Tigris River (Thureau-Dangin et al. 1931: 43-44; Thureau-Dangin \& Dunand 1936: 24, plan B, pl. 42.1; Miglus 1996: 96-97; Matney et al. 2002: 69-70, fig. 25-27; Blaylock 2009: 134-38; Bunnens 2016; Marchetti 2016: 37a, fig. 13).

\section{Concluding remarks}

The practice of arranging small pebbles in chequerboard patterns is well attested in Syro-Hittite culture as well as in Assyrian provincial palaces; it may originate in local traditions or be a Western influence. The earlier and more sophisticated evidence for polychrome flooring in the Iron Age is documented in central Anatolia, at Phrygian Gordion. Until now, the Mycenean pavement at Tiryns has been considered the earliest-documented example of mosaic flooring (Podzuweit \& Salzmann 1977: 136); this dates to the mid second millennium BC, but it does not employ precise designs or polychrome pebbles (Salzmann 1982: 5, 114, fig. 1.1). As the earliest polychrome, geometric mosaic stone floor, the Uşaklı Höyük pavement could represent a Late Bronze Age Anatolian forerunner for later polychromatic mosaic floors. It remains difficult to see a logical stylistic development between the Uşaklı pavement and the Phrygian or Syro-Hittite examples, but Uşaklı provides the first evidence of a polychromatic mosaic floor, with clear patterning, of Hittite date and a possible inspiration for later pebble mosaic floors.

\section{References}

Blaylock, S. 2009. Tille Höyük 3. The Iron Age: introduction, stratification and architecture. London: British Institute at Ankara.

Bunnens, G. 2016. Neo-Assyrian pebble mosaics in their architectural context, in J. MacGinnis, D. Wicke \& T. Greenfield (ed.) The archaeology of the Assyrian Empire: 59-70. Cambridge:

McDonald Institute for Archaeological Research.

Marchetti, N. 2016. The 2014 joint Turco-Italian excavations at Karkemish. Kazı Sonuçları Toplantisz 37: 363-80.

Matney, T., M. Roaf, J. MacGinnis \& H. McDonald. 2002. Archaeological excavations at Ziyaret Tepe 2000-2001. Anatolica 28: 47-89.
Mazzoni, S., A. D’Agostino \& V. Orsi. 2019. Exploring a site in the north central Anatolian Plateau: archaeological research at Uşaklı Höyuük (2013-2015). Asia Anteriore Antica 1: 57-142.

MielKe, D.P. 2011. Hittite cities: looking for a concept, in H. Genz \& D.P. Mielke (ed.) Insights into Hittite history and archaeology: 153-94. Leuven: Peeters.

Miglus, P.A. 1996. Das Wohngebiet von Assur: Stratigraphie und Architektur. Leipzig: Hinrichs.

Müller-Karpe, A. 2017. Sarissa. Die Wiederentdeckung einer hethitischen Königsstadt. Darmstadt: Philipp von Zabern.

Naumann, R. 1955. Architektur Kleinasiens von ihren Anfängen bis zum Ende der hethitischen Zeit. Tübingen: Wasmuth. 
Neve, P. 1982. Büyükkale. Die Bauwerke. Grabungen 1954-1966. Berlin: Mann.

Orsi, V. 2018. Reading the Late Bronze Age ceramic evidence at Uşaklı Höyük (central Turkey): the pottery from the area A test sounding. Anatolica 44: 179-211.

ÖzGüç, T. 1966. Altıntepe: Mimarlık anıtları ve duvar resimleri. Architectural monuments and wall paintings. Ankara: Türk Tarih Kurumu Basımevi.

Podzuweit, C. \& D. Salzmann. 1977. Ein mykenischer Kieselmosaik-fussboden aus Tiryns. Archäologischer Anzeiger 92: 123-37.
SalzmanN, D. 1982. Untersuchungen zu den antiken Kieselmosaiken: von den Anfängen bis zum Beginn der Tesseratechnik. Berlin: Gebr. Mann.

SüEL, M. 2008. Bir Hitit Başkenti Ortaköy Şapinuva. Ankara: Uyum Ajans.

Thureau-Dangin, F., A. Barrois, G. Dossin \& M. Dunand. 1931. Arslan-Tash. Paris: Geuthner.

Thureau-Dangin, F. \& M. Dunand. 1936. Til-Barsip. Paris: Geuthner.

Young, S.R. 1965. Early mosaics at Gordion. Expedition Magazine 7(3): 4-13. Available at http://www.penn.museum/sites/expedition/? p=987 (accessed 10 October 2019).

Received: 9 July 2019; Revised: 16 July 2019; Accepted: 21 July 2019

(C) Antiquity Publications Ltd, 2019 